\title{
Costs and benefits of agricultural ammonia emission abatement options for compliance with European air quality regulations
}

\author{
Elias Giannakis ${ }^{1 *} \mathbb{D}$, Jonilda Kushta ${ }^{1}$, Adriana Bruggeman ${ }^{1}$ and Jos Lelieveld ${ }^{1,2}$
}

\begin{abstract}
Background: In Europe, ammonia $\left(\mathrm{NH}_{3}\right)$ emissions strongly contribute to fine particulate matter (PM2.5) pollution and associated premature human mortality. The National Emission Ceilings Directive 2016/2284/EU has set an obligation for all European Union countries to reduce the $\mathrm{NH}_{3}$ emissions by $6 \%$, relative to 2005 , by 2020 . This study aims to assess the costs and benefits of four $\mathrm{NH}_{3}$ emission abatement options for the compliance of the agricultural sector with the commitments of the European air quality regulatory framework. A regional atmospheric model (WRF/Chem) was used to assess the effects of regulating $\mathrm{NH}_{3}$ emissions reductions on PM2.5 concentrations over Europe. Nonmarket valuation techniques (value of statistical life) were used to monetize the associated health outcomes.

Results: We calculated that 16 out of the $28 \mathrm{EU}$ member states exceeded their $2020 \mathrm{NH}_{3}$ emission ceilings in 2016. The highest exceedances from the 2020 emission commitment level occurred in Latvia (15\%), Germany (12\%) and the UK (12\%). Simulation of the required $\mathrm{NH}_{3}$ emission reduction by WRF/Chem showed that relatively large reductions in PM2.5 concentrations occur over central-western Europe and the UK. The largest health benefits (> 5\% reduction in premature mortality) were found for Scandinavia. The economic benefit from avoided premature deaths over Europe amounts to 14,837 M€/year. The costs of four $\mathrm{NH}_{3}$ emission abatement options, where each would fully achieve the required emission reduction, range from $80 \mathrm{M€} /$ year for low nitrogen feed to $3738 \mathrm{M€/year} \mathrm{for} \mathrm{low-emission} \mathrm{animal}$ housing, with covered manure storage (236 M€/year) and urea fertilizer application (253 M€/year), in between.

Conclusion: Our analysis indicates that the costs of compliance by the agricultural sector with the commitments of the European air quality regulations are much lower than the economic benefit. Thus, much more ambitious reduction commitments for $\mathrm{NH}_{3}$ emissions could be applied by the EU-28. The monetization of the health benefits of $\mathrm{NH}_{3}$ emission abatement policies and the assessment of the implementation costs can help policy-makers devise effective air pollution control programmes.
\end{abstract}

Keywords: Ammonia emissions, WRF/Chem, Value of statistical life, PM2.5 in Europe, Premature mortality, CAP

\section{Background}

Air pollution, especially fine particulate matter with a diameter smaller than $2.5 \mu \mathrm{m}$ (PM2.5), has been associated with many adverse health impacts. Exposure to PM2.5 and ozone is considered responsible about for 4.55 million premature deaths annually worldwide, of which 274,000 per year (i.e., 6\%) are reported for European

\footnotetext{
*Correspondence: e.giannakis@cyi.ac.cy

1 The Cyprus Institute, Energy Environment and Water Research Center, 20 Konstantinou Kavafi Street, Aglantzia, 2121 Nicosia, Cyprus

Full list of author information is available at the end of the article
}

Union (EU) [46]. Recent studies have revealed a large ( $40 \%$ or higher) contribution of agricultural emissions to PM2.5 pollution in many European countries [6, 45]. For example, in Germany the contribution by agriculture to PM2.5 and associated premature mortality is about $45 \%$ [45].

Ammonia $\left(\mathrm{NH}_{3}\right)$ emissions, which originate for $96 \%$ from agricultural activities, significantly contribute to the formation of secondary particulate matter and in particular to the formation of PM2.5 [7]. Giannakis et al. [31] modelled the effect of a $20 \%$ increase in the output of 
the EU-28 agricultural sector on air pollution in Europe. Their findings indicate a large increase of PM2.5 concentrations, the highest of which would occur over the northern Balkan countries (Bulgaria and Romania) and northern Italy. The regulation of agricultural $\mathrm{NH}_{3}$ emissions has been considered the most effective control strategy for reducing PM2.5 in Europe [28, 34, 49]. Pozzer et al. [56] found that a $50 \%$ decrease of $\mathrm{NH}_{3}$ emissions could reduce the annual, geographical average near-surface PM2.5 concentrations by about $11 \%$ across Europe, while with maximum emission controls up to $35 \%$ reduction would be possible.

Significant progress towards the reduction of anthropogenic air pollution emissions has been achieved over the past 20 years in Europe, mainly driven by policy regulations such as the first national emission ceilings (NEC) directive (2001/81/EC). Most significantly, from 2005 to 2016 sulphur dioxide $\left(\mathrm{SO}_{2}\right)$, nitrogen oxides (NOx), non-methane volatile organic compounds (NMVOC) and PM2.5 emissions fell by $70 \%, 37 \%, 28 \%$ and $21 \%$, respectively [23]. However, agriculture is the sector in which air pollutant emissions has decreased least. Within the EU-28, emissions of $\mathrm{NH}_{3}$ from agriculture have decreased by a mere 5\% from 2005 to 2013 [21]. On the contrary, from 2013 onwards, $\mathrm{NH}_{3}$ emissions have slightly increased again (+3\% from 2013 to 2016) [21].

The main legislative instrument to achieve the 2030 objectives of the Clean Air Programme is the National Emission Ceilings Directive 2016/2284/EU, which sets national reduction commitments for EU-28 countries for five important atmospheric pollutants, namely, sulphur dioxide $\left(\mathrm{SO}_{2}\right)$, nitrogen oxides ( $\left.\mathrm{NOx}\right)$, non-methane volatile organic compounds (NMVOC), ammonia $\left(\mathrm{NH}_{3}\right)$ and PM2.5. Each EU-country is required to formulate and implement a national air pollution control programme by 2019 , and every 4 years thereafter set out the measures to comply with the 2020 and 2030 reduction commitments (Directive 2016/2284/EU). For agriculture, each EUcountry is required to establish a national advisory code of good agricultural practice to control $\mathrm{NH}_{3}$ emissions.

Contrary to most production sectors, there is no extensive body of EU legislation focused on reducing air pollution from agriculture. Little support for $\mathrm{NH}_{3}$ reduction has been provided by the Common Agricultural Policy (CAP) [17], although within the second pillar of the CAP, i.e., rural development policy, a number of emissionreducing support measures exists such as the measure 'investments in physical assets' (e.g., investments in low-emission manure storage and spreading facilities), as well as the 'agri-environment-climate' measures. However, the current reform of the legislative framework of the CAP for the period 2021-2027 identifies the improvement of air quality as a priority [19]. Moreover, agriculture was a focus topic of the First Clean Air Forum organized by the European Commission in Paris (November 2017), where over 300 participants from government, industry and non-governmental organizations shared their views and perspectives for reducing $\mathrm{NH}_{3}$ emissions from agricultural activities [18]. Agriculture is also one of the three thematic topics of the Second Clean Air Forum (2019) of the European Commission in Slovakia in November 2019.

According to the theoretical framework of Houlton et al. [39], the first target for solving the global nitrogen balance is the improvement of nitrogen-use efficiency for food production. However, a quantitative analysis of the costs and benefits of technologies improving nitrogenuse efficiency is currently missing [39]. We aim to fill this gap and empirically investigate the costs and benefits of regulating $\mathrm{NH}_{3}$ emissions for the compliance of the agricultural sector of EU countries with the commitments of the National Emission Ceilings Directive 2016/2284/EU. The specific objectives of the study are: (i) to estimate the required national $\mathrm{NH}_{3}$ emission reductions across the EU-28; (ii) to model the effects of these reductions on PM2.5 concentrations over Europe; (iii) to estimate and monetize the resulting reduced premature mortality; (iv) to assess the costs of the required $\mathrm{NH}_{3}$ emission abatement options.

\section{Methods \\ National ammonia emission reduction commitments by 2020}

The National Emission Ceilings Directive 2016/2284/EU has set an obligation for all EU countries to reduce the $\mathrm{NH}_{3}$ emissions by $6 \%$, relative to 2005 , by 2020 . By 2030 a more ambitious reduction commitment is set at $19 \%$. Here, we identify which countries have exceeded their $2020 \mathrm{NH}_{3}$ emission ceilings in 2016 and estimate the required reduction of $\mathrm{NH}_{3}$ emissions to comply with the 2020 commitments.

\section{Atmospheric chemistry model}

The Weather Research and Forecast model coupled with the chemistry module (WRF/Chem) [24] was used in this study to assess the effects of reduction in $\mathrm{NH}_{3}$ emissions on PM2.5 concentrations over Europe. WRF/Chem is a fully coupled regional atmospheric transport and chemistry model based on the meteorological core of the WRF model [33], which includes various options of gas-phase chemistry and aerosol microphysics mechanisms. The model uses a terrain-following hydrostatic-pressure vertical coordinate system. In this study 27 layers are used, from the surface up to $50 \mathrm{hPa}$, with an average height of $70 \mathrm{~m}$ for the model layer closest to the surface. Table 4 
summarizes the configuration of the model used in this study.

WRF/Chem has been widely used in atmospheric studies across Europe and evaluation under various conditions has shown that the WRF/Chem performance over Europe qualifies as state-of-the-art modelling system [8, 60]. Kushta et al. [44] compared WRF/Chem simulated mean annual PM2.5 concentrations, using a similar configuration as the current study, against observed PM2.5 concentrations from the AIRBASE monitoring network over Europe, and concluded that more than $95 \%$ of the simulated data fell within a factor two of the observations. For health assessment studies Kushta et al. [44] showed that the uncertainties derived from the model performance are minor compared to the uncertainties introduced by the assumptions related to exposure risk factors. In that study, the authors also found that there was only $10 \%$ difference between the mortality rates over the EU-28 from satellite-derived PM2.5 mean annual concentrations and those derived from the WRF/Chem simulations.

We conducted year-long simulations with meteorological forcing from the National Center for Environmental Prediction (NCEP) global forecast system (GFS) and chemical boundary conditions from global simulations with MOZART-4 (Model for Ozone and Related chemical Tracers version 4; [16] for the year 2015. Emission estimates were taken from the global emission dataset
EDGAR-HTAP v2 at a resolution of $0.1^{\circ} \times 0.1^{\circ}$ for nitrogen and sulphur oxides (NOx and SOx), non-methane volatile organic compounds (NMVOC), carbon monoxide $(\mathrm{CO})$, ammonia $\left(\mathrm{NH}_{3}\right)$ and fine and coarse particulate matter (PM2.5 and PM10) [41]. Simulations were performed at a horizontal grid spacing of $50 \mathrm{~km}$ covering the wider European region shown in Fig. 1. Two annual simulations were performed: (i) simulation 1 with the standard emission inventory available in WRF/Chem (WCcntr) and (ii) simulation 2 with the country-based $\mathrm{NH}_{3}$ emission reductions according to the national emission reduction commitments from $2020\left(\mathrm{WC}_{\mathrm{NH} 3}\right)$.

\section{Health impacts}

The annual mean PM2.5 concentrations derived from the two simulations of WRF/Chem were used to estimate reduced premature mortality rates for a range of related diseases and age groups, based on integrated exposureresponse (IER) functions [10]. For the calculation of the relative risk (RR) factors we used the updated parameters used for the global burden of disease study (GBD) for 2015 [13]. Recently, new IER functions have become available, indicating much higher premature mortality rates [11], but here we apply the estimates that are consistent with the GBD [13]. The IER functions were applied to account for health effects of PM2.5 related to ischaemic heart disease, cerebrovascular disease, lower respiratory tract infections, chronic obstructive pulmonary

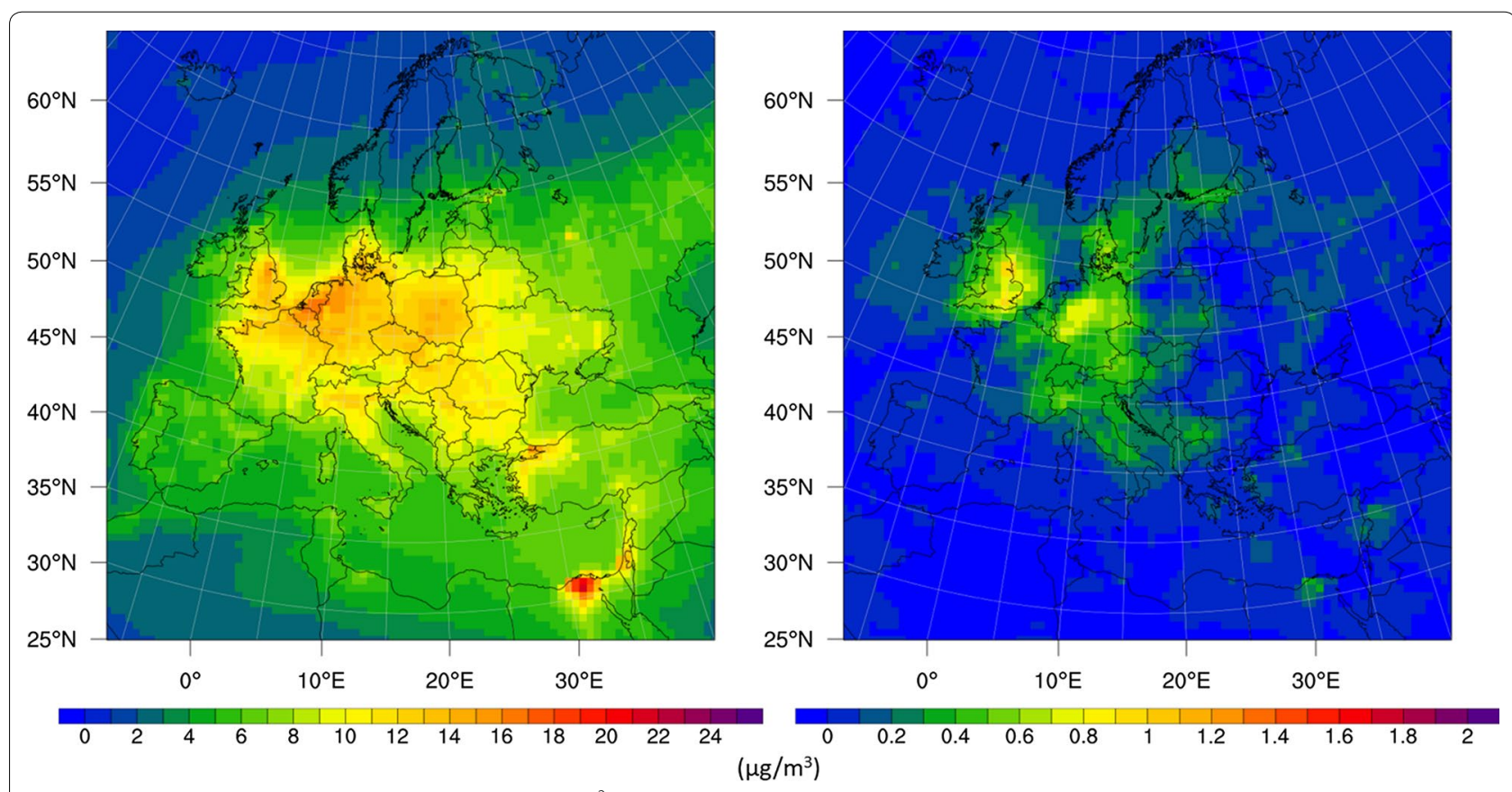

Fig. 1 Mean annual PM2.5 surface concentrations $\left(\mu \mathrm{g} / \mathrm{m}^{3}\right.$ ) from the control (WCcntr) simulation (left) and difference in PM2.5 concentrations ( $\mu \mathrm{g} /$ $\mathrm{m}^{3}$ ) between the WCcntr and the $\mathrm{NH}_{3}$ emission reduction $\left(\mathrm{WC}_{\mathrm{NH} 3}\right.$ ) simulation (right) 
disease and lung cancer. Note that the new IER functions of Burnett et al. [11] include additional non-communicable diseases, not yet accounted for by the GBD [13]. Hence our results should be regarded as conservative health impact estimates. The respective burden of disease was analysed for the following age groups: below 5 years, $5-14,15-29,30-49,50-69$, and 70 and older. Countrylevel baseline mortality rates for each of the diseases representative of the year 2015 and the population data for the countries included in our domain were taken from the WHO Global Health Observatory (http://www.who. int/gho/database/en/). We estimate a $95 \%$ confidence interval with the use of the IER functions, as described in Cohen et al. [13] and in GBD [26], for the uncertainty estimates of the economic value of the reduction in $\mathrm{NH}_{3}$ emissions (see "Economic valuation of mortality").

\section{Economic valuation of mortality}

The monetary valuation of the risk of premature death relies on non-market valuation methods. The value of statistical life (VSL) is the most widely used metric to monetize premature mortality risks associated to air pollution $[28,51]$ and was applied in this study to calculate the benefits of policies reducing $\mathrm{NH}_{3}$ emissions from agriculture. The VSL is the marginal rate of substitution between wealth and mortality risk, and is defined as the rate at which people trade off income for mortality risk reduction [35]:

$$
\mathrm{VSL}=\frac{\partial \mathrm{WTP}}{\partial p}
$$

where $p$ is the mortality risk; WTP is the individual's willingness to pay to reduce mortality risk by $\Delta p$.

Similar to Ghude et al. [27] and Giannadaki et al. [28], we used the VSL base value of 3 million USD (in 2005USD) derived by the OECD [51] meta-analysis study to estimate the VSL for the individual countries (EU and non-EU; see Table 5), adjusting for differences in income and economic growth as suggested in OECD [51, 52]. The equation is given as:

$$
\begin{aligned}
\operatorname{VSL}_{i, 2016}= & \operatorname{VSL}_{\mathrm{OECD}, 2005} \times\left(\frac{Y_{i, 2005}}{Y_{\mathrm{OECD}, 2005}}\right)^{\beta} \\
& \times\left(1+\% \Delta P_{i, 2005-2016}+\% \Delta G_{i, 2005-2016}\right)^{\beta},
\end{aligned}
$$

where $\mathrm{VSL}_{i, 2016}$ is the adjusted VSL for country $i$ in 2016; VSL ${ }_{\mathrm{OECD}}, 2005$ is the VSL base value for OECD countries in 2005; $Y_{i, 2005}$ is the GDP per capita in country $i$ in 2005 in PPP (purchasing power parity); $Y_{\mathrm{OECD}, 2005}$ is the average GDP per capita in OECD countries in 2005 in PPP; $\beta$ is the income elasticity of VSL and equals to 0.8 as recommended by OECD [51, 52]; $\% \Delta P_{i, 2005-2016}$ and
$\% \Delta G_{i, 2005-2016}$ are price inflation/deflation and GDP per capita increase/decrease in country $i$ between 2005 and 2016, respectively. We use the expected VSL range of 1.5-4.5 million USD [51] for the uncertainty estimates of our analysis, as explained below.

The annual economic value of reduction in $\mathrm{NH}_{3}$ emissions $(E V)$ was calculated by multiplying the number of premature deaths expected to be prevented in a given year in country $i\left(L_{i}\right)$ with the respective $\mathrm{VSL}_{i}$ as follows:

$$
\mathrm{EV}=\left(L_{i}\right) \times\left(\mathrm{VSL}_{i}\right) .
$$

We use the fractional uncertainties of $L_{i}$ and $\mathrm{VSL}_{i}$ to estimate the uncertainty range of the economic value of reduction in $\mathrm{NH}_{3}$ emissions (EV) as follows [25]:

$$
\delta \mathrm{EV}=\sqrt{\left(\frac{\delta L}{L}\right)^{2}+\left(\frac{\delta \mathrm{VSL}}{\mathrm{VSL}}\right)^{2}} \times \mathrm{EV},
$$

where $\delta L$ is the absolute value of the upper or lower bound minus the mean of $L$ and similarly for $\delta$ VSL.

\section{Costs of ammonia emission abatement options}

A set of measures for reducing $\mathrm{NH}_{3}$ emissions from agriculture is included in Directive 2016/2284/EU, such as livestock feeding strategies, low-emission manure storage systems, low-emission animal housing systems, techniques for limiting $\mathrm{NH}_{3}$ emissions from the use of mineral fertilizers. The efficiency of these measures has been investigated for the EU by Klimont and Winiwarter [42] and Oenema et al. [53]. Oenema et al. [53] used the Greenhouse gas-Air pollution INteractions and Synergies (GAINS) model, developed by the International Institute of Applied Systems Analysis (IIASA), to estimate the cost of $\mathrm{NH}_{3}$ emission abatement options in $€$ per kg nitrogen $(\mathrm{kg} \mathrm{N})$ removed per year.

Here, we selected four $\mathrm{NH}_{3}$ emission abatement options, three for the livestock sector: (i) low nitrogen feed; (ii) manure storage capacity; (iii) low-emission animal housing; and one for the crop sector: (iv) techniques to improve or substitute urea fertilizer application. These four measures form the basic instruments for establishing the national advisory code of agricultural practice to control $\mathrm{NH}_{3}$ emissions according to the UNECE Framework Code for Good Agricultural Practice for Reducing Ammonia Emissions of 2014 (Directive 2016/2284/EU). We computed the total annual costs for 2016, for each measure, based on Oenema et al. [53], for the countries that exceeded their national $\mathrm{NH}_{3}$ emission ceilings (see "Exceedance of 2020 national ammonia emission reduction commitments"). The computed costs cover the total cost of achieving a country's required emission reduction, while in reality a country could select to apply a combination of these four measures. For the uncertainty 
range of the costs of the emission control measures we use the 25 th and 75 th percentile values specified by Oenema et al. [53].

\section{Results and discussion}

Exceedance of 2020 national ammonia emission reduction commitments

We calculated that 16 out of the $28 \mathrm{EU}$ member states exceeded their $2020 \mathrm{NH}_{3}$ emission ceilings in 2016 . The reduced $\mathrm{NH}_{3}$ emissions (tonnes) required to meet air quality targets for the 16 countries are presented in Table 1. The highest deviations from the 2020 emission commitment level ( $>10 \%$ above the maximum 2020 2029 emissions) occurred in Latvia (15\%), Germany, Estonia and the UK (12\%), Sweden (11\%) and Finland (10\%) (Table 1).

\section{Air quality impact}

The mean annual modelled PM2.5 surface concentrations over Europe and the reduction in PM2.5 burden due to the reduction of $\mathrm{NH}_{3}$ emissions are shown in Fig. 1. The difference in PM2.5 concentrations $\left(\mu \mathrm{g} / \mathrm{m}^{3}\right)$ is expressed as $\mathrm{WC}_{\mathrm{cntr}}-\mathrm{WC}_{\mathrm{NH} 3}$, where $\mathrm{WC}_{\mathrm{cntr}}$ and $\mathrm{WC}_{\mathrm{NH} 3}$ represent the mean annual surface concentrations of PM2.5 from the control simulation (cntr) and from the $\mathrm{NH}_{3}$ emission reduction simulation $\left(\mathrm{NH}_{3}\right)$. The PM2.5 concentrations and the impact of reducing $\mathrm{NH}_{3}$ emissions were assessed for each of the 16 selected EU countries, for the EU-28 and for a number of neighbouring countries (see Table 5).

Near-surface modelled PM2.5 concentrations exhibit a peak over Central Europe and Poland and Benelux countries with mean annual concentrations reaching $16-18 \mu \mathrm{g} / \mathrm{m}^{3}$, which is below the current EU limit of $25 \mu \mathrm{g} / \mathrm{m}^{3}$, but well in excess of the guideline of $10 \mu \mathrm{g} / \mathrm{m}^{3}$ of the World Health Organization (WHO). Other regions with pronounced PM2.5 levels include the northern part of Italy with local sources such as transport and diffuse regional sources such as industrial fossil fuel and biomass burning [55] and major megacities in the Southeastern Europe such as Istanbul, Greater Cairo area and along the coast of Israel where major coal power plants are located [3].

The distribution of the differences in near-ground concentrations from the application of the $\mathrm{NH}_{3}$ emission abatement measures shows a PM2.5 maximum over central-western Europe, collocated to a large extent with the required $\mathrm{NH}_{3}$ emission reductions to meet the 2020 commitments of the National Emission Ceilings Directive 2016/2284/EU, especially over Germany and UK (see Table 1). Very small differences occur over Eastern Europe with concentrations affected by less than $0.3 \mu \mathrm{g} \mathrm{m}^{-3}$. Bessagnet et al. [9] quantified the impact of additional reductions of $\mathrm{NH}_{3}$ emissions beyond the Gothenburg Protocol requirements on PM2.5 concentrations in the EU-27 and demonstrated that the most

Table 1 Reported $\mathrm{NH}_{3}$ emissions for 2005 and 2016, $\mathrm{NH}_{3}$ emissions reduction to meet 2020 emission commitment level, for the $16 \mathrm{EU}$ countries that exceeded this level in 2016

\begin{tabular}{|c|c|c|c|c|c|}
\hline Countries & $\begin{array}{l}\text { Reported } \mathrm{NH}_{3} \\
\text { emissions in } 2005 \\
\text { (tonnes/year) }\end{array}$ & $\begin{array}{l}\mathrm{NH}_{3} \text { emissions } \\
\text { reduction to meet } \\
2020 \text { commitments } \\
(\%, \text { relative to } 2005)\end{array}$ & $\begin{array}{l}\text { Reported } \mathrm{NH}_{3} \\
\text { emissions in } 2016 \\
\text { (tonnes/year) }\end{array}$ & $\begin{array}{l}\mathrm{NH}_{3} \text { emissions } \\
\text { reduction to meet } \\
2020 \text { commitments } \\
\text { (\%, relative to 2016) }\end{array}$ & $\begin{array}{l}\mathrm{NH}_{3} \text { emissions } \\
\text { reduction to meet } 2020 \\
\text { commitments in } 2016 \\
\text { (tonnes) }\end{array}$ \\
\hline Bulgaria & 42,915 & 3 & 42,282 & 2 & 654 \\
\hline Denmark & 83,121 & 24 & 70,769 & 11 & 7597 \\
\hline Germany & 580,691 & 5 & 629,236 & 12 & 77,580 \\
\hline Estonia & 9373 & 1 & 10,563 & 12 & 1284 \\
\hline Ireland & 110,574 & 1 & 115,528 & 5 & 6060 \\
\hline Spain & 445,102 & 3 & 448,825 & 4 & 17,076 \\
\hline France & 585,320 & 4 & 591,415 & 5 & 29,508 \\
\hline Latvia & 11,906 & 1 & 13,947 & 15 & 2160 \\
\hline Luxembourg & 5689 & 1 & 6189 & 9 & 557 \\
\hline Hungary & 80,226 & 10 & 78,417 & 8 & 6214 \\
\hline Austria & 60,024 & 1 & 63,791 & 7 & 4367 \\
\hline Portugal & 47,810 & 7 & 45,716 & 3 & 1253 \\
\hline Slovakia & 33,591 & 15 & 28,960 & 1 & 408 \\
\hline Finland & 31,677 & 20 & 28,132 & 10 & 2790 \\
\hline Sweden & 48,986 & 15 & 46,747 & 11 & 5109 \\
\hline United Kingdom & 241,296 & 8 & 253,045 & 12 & 31,053 \\
\hline EU-16 & 2418,301 & 6 & $2,473,562$ & 8 & 193,668 \\
\hline
\end{tabular}


important reductions took place in the main $\mathrm{NH}_{3}$ source areas (e.g., over the south of England, north of France, Germany, Czech Republic and Poland), i.e., the agriculturally intensive regions; they found that the efficiency of reductions in $\mathrm{NH}_{3}$ emissions was highest for relatively large reduction rates. Similarly, Backes et al. [4] analysed the source distribution patterns in Europe using the emission model SMOKE, and demonstrated that the largest $\mathrm{NH}_{3}$ emissions occur in hotspots where the livestock density is high, for example in intensively housed animal production systems in the Po-valley, Denmark, Brittany, Belgium and the Netherlands.

Ammonia emissions contribute to the formation of the main two inorganic aerosol components over Europe, ammonium nitrate $\left(\mathrm{NH}_{4} \mathrm{NO}_{3}\right)$ and ammonium sulfate $\left(\left(\mathrm{NH}_{4}\right)_{2} \mathrm{SO}_{4}\right)$, with the first being most abundant near source regions and the second further downwind due to the slower formation rate and its pronounced stability [31]. Ammonium nitrate results from the reaction between ammonia and nitric acid, a process that competes with the slower-rate neutralization of sulfuric acid in the atmosphere that leads to the formation of the more thermodynamically stable ammonium sulfate aerosols. Park et al. [54] showed that during transport away from the $\mathrm{NOx}$ and $\mathrm{NH}_{3}$ source areas, and especially at relatively high temperatures, e.g., during summer, $\mathrm{NH}_{4} \mathrm{NO}_{3}$ can rapidly volatilize, in contrast to $\left(\mathrm{NH}_{4}\right)_{2} \mathrm{SO}_{4}$. Thus, $\mathrm{NH}_{4} \mathrm{NO}_{3}$ is mostly present near source areas and contributes to PM2.5 over emission source regions. This process explains that the reduction imposed in this sensitivity test does not strongly affect aerosol concentrations remote from the emission sources, with larger differences collocated with main emitting countries (and the ones with the larger reduction in $\mathrm{NH}_{3}$ primary emissions).

It is anticipated that $\mathrm{NH}_{3}$ control effectiveness could be influenced by simultaneous changes in other pollutants such as $\mathrm{SO}_{2}$ and $\mathrm{NOx}$ [5]. These changes can either come about as a result of interactions between industrial sectors as described in Giannakis et al. [31] and/or derive from additional measures aimed at the most strongly SOx and NOx emitting sectors such as traffic, energy production and consumption and several manufacturing industries.

Ammonia emission control measures may lead to improved air quality and reduced premature mortality, however, they could affect the intensity and spatial distribution of acid rain impacts on ecosystems. Recently, Liu et al. [48] showed that while ammonia emission abatement measures could prove a strategic option to mitigate haze pollution, it could also worsen the acid rain intensity and spatial distribution in China, possibly partly offsetting the benefit from better air quality and less nitrogen deposition. They concluded that there are, however, region-specific patterns in this complex mechanism. For example, in many soils nitrifying bacteria transform ammonium into nitrate, which enhances acidification. Thus, there is a need for region-specific strategies for multipollutant controls that will benefit both human and ecosystem health. The present study presents an assessment of the benefit that would derive from agricultural $\mathrm{NH}_{3}$ emission abatement options, rather than considering scenarios in which other sectors/pollutants are being considered as well.

\section{Health assessment}

Next, we quantified the potential health benefits over the domain resulting from the reduction of $\mathrm{NH}_{3}$ emissions $\left(\mathrm{WC}_{\mathrm{NH} 3}\right)$. The most positively affected countries, compared to the control run ( $>5 \%$ reduction in premature mortality), in terms of relative change, are located in Scandinavia, i.e., the reduction in premature mortality was $13 \%$ in Finland, that is, 80 less premature deaths per year (95\% confidence interval (CI95): 39-110), 9\% in Sweden (162, CI95: 87-192) and 9\% in Norway (32, CI95: 15-42) as summarized in Table 2. In terms of absolute values of excess deaths that could be avoided with the compliance of agriculture to the commitments of the National Emission Ceilings Directive 2016/2284/EU, Germany is expected to have the largest benefit (930) followed by UK (928) and Italy (448) (Table 6). Here, we have to note that changes in excess mortality do not follow a linear relationship with PM2.5 concentrations. The IER functions tend to "flatten" towards higher PM2.5 concentrations, and air pollution control measures can be particularly effective at relatively low levels [13]. Scandinavian countries have relatively low reference air pollution levels, thus their relative reduction in mortality from PM2.5 is larger than that in more polluted regions. Similar findings were reported by Giannadaki et al. [28] who estimated that large-scale reduction in $\mathrm{NH}_{3}$ emissions in the EU-28, i.e., by $50 \%$, could reduce associated premature mortality by $18 \%$, resulting in an annual economic benefit of 89 billion USD. They found the largest reductions in premature mortality in Estonia (70\%), Finland (58\%), Norway (56\%) and Sweden (45\%).

As mentioned above, the mortality burden estimates in Europe could be higher using the most recent epidemiological models [11, 47, 62, 64], suggesting that improving air quality and applying associated policy measures could potentially lead to greater health benefits than previously thought. In these recent studies, more accurate hazard ratio functions that associate PM2.5 concentrations with the health response have been produced, using new data from additional and geographically extended epidemiological studies, including studies of long-term air pollution exposure that cover the very low and very 
Table 2 Reduction in premature mortality resulting from the reduction of ammonia emissions over Europe in 2016

\begin{tabular}{|c|c|c|c|}
\hline $\begin{array}{l}\text { Countries with }>5 \% \text { reduction } \\
\text { in premature mortality }\end{array}$ & $\begin{array}{l}\text { Countries with } 2-5 \% \text { reduction } \\
\text { in premature mortality }\end{array}$ & $\begin{array}{l}\text { Countries with } 1-2 \% \text { reduction } \\
\text { in premature mortality }\end{array}$ & $\begin{array}{l}\text { Countries with }<1 \% \\
\text { reduction in premature } \\
\text { mortality }\end{array}$ \\
\hline Finland & United Kingdom & Bosnia and Herzegovina & Slovakia \\
\hline Sweden & Denmark & Northern Macedonia & Spain \\
\hline Norway & Austria & Slovenia & Hungary \\
\hline Estonia & Germany & Albania & Poland \\
\hline \multirow[t]{10}{*}{ Ireland } & Italy & France & Bulgaria \\
\hline & Switzerland & Croatia & Latvia \\
\hline & Luxembourg & Czech Republic & Romania \\
\hline & Portugal & Belgium & Jordan \\
\hline & & Montenegro & Ukraine \\
\hline & & Serbia & Georgia \\
\hline & & Netherlands & Turkey \\
\hline & & Cyprus & \\
\hline & & Greece & \\
\hline & & Lebanon & \\
\hline
\end{tabular}

high ends of the PM2.5 concentration range of mean exposures. Burnett et al. [11] used worldwide mortality data from all non-communicable diseases as well as pneumonia instead of the five major ones (ischaemic heart disease, cerebrovascular disease, lower respiratory tract infections, chronic obstructive pulmonary disease and lung cancer) upon which the IER mortality is based. Based on the new Global Exposure Mortality Model (GEMM) described in Burnett et al. [11], Lelieveld et al. [47] showed that the use of the GEMM for Europe results in more than twice the number of premature deaths per year, mostly due to PM2.5 exposure, compared with the Global Burden of Disease estimate that is based on previous IER functions [10, 13, 26]. Wang et al. [64] showed that in California the GEMM approach resulted in a greater PM2.5-associated mortality burden than the more conventional log-linear function (all-cause mortality derived from Krewski et al. [43] and Hoek et al. [37] and the previous IER functions [10]. The authors argue that the true relationship between mortality and PM2.5 exposure has not yet been established. Despite the fact that the uncertainties and discrepancies among the existing concentration response functions in the literature could pose a limitation to the current study and warrant further research, these limitations will be towards higher mortality estimates and associated benefits rather than lower ones. Our findings indicate that the PM2.5 exposure in Europe can have significant health effects, and changes from agricultural policy measures can lead to substantially reduced excess mortality and financial benefits. Recent new epidemiologic evidence strongly corroborates that these substantial health benefits associated with PM2.5 control could have been underestimated.

\section{Cost-benefit assessment of ammonia emission abatement options}

The estimated costs of $\mathrm{NH}_{3}$ emission abatement options over Europe are shown in Table 3. The estimated annual costs for 2016 of $\mathrm{NH}_{3}$ emission control measures to achieve the emission reduction commitments amount from $80 \mathrm{M} €$ (uncertainty range $(r)$ : 70-89 $\mathrm{M} €$ ) (low nitrogen feed) to $3738 \mathrm{M} €(r$ :3357-4118 M€) (low-emission animal housing), which correspond to $46 € /$ year per farm with livestock for low nitrogen feed option and $2176 € /$ year per farm with livestock for low-emission animal housing option in the $16 \mathrm{EU}$ countries. The highest cost per livestock holding is expected in Germany for both measures, that is, $173 €$ /year/holding (low nitrogen feed) and $8107 € /$ year/holding (low-emission animal housing). These cost estimates ( $80 \mathrm{M} €$ and $3738 \mathrm{M} €$ ) represent around $0.1 \%$ and $6.3 \%$, respectively, of the total 2014-2020 European Agricultural Fund for Rural Development (EAFRD) funding of the 16 studied EU countries [20]. Similarly, the estimated annual cost for the covered manure storage option is $236 \mathrm{M} €$ (corresponding to $137 € /$ year/farm with livestock), and for improving the application of urea fertilizer option it is $253 \mathrm{M€}$ (corresponding to $161 € /$ year/crop farm) in the $16 \mathrm{EU}$ countries.

The annual economic benefit from the avoided premature deaths due to the regulation of $\mathrm{NH}_{3}$ emissions in the $16 \mathrm{EU}$ countries is $10,370 \mathrm{M} €(r: 4843-15,706 \mathrm{M} €)$, which translates into $31 € /$ year per EU-16 citizen $(r$ : 15-47 $€ /$ 
Table 3 Costs of four ammonia emission abatement options, computed based on Oenema et al. [53]—each option would fully achieve the 2020 national emission reduction commitments, in 2016-and benefits of meeting these commitments, derived from WRF/Chem model simulations, integrated exposure-response (IER) functions and value of statistical life (VSL) metric

\begin{tabular}{|c|c|c|c|c|c|}
\hline & $\begin{array}{l}\text { Cost of low } \\
\text { nitrogen feed } \\
\text { (M€) }\end{array}$ & $\begin{array}{l}\text { Cost of covered } \\
\text { manure storage }(M €)\end{array}$ & $\begin{array}{l}\text { Cost of improving } \\
\text { or substituting urea } \\
\text { fertilizer application } \\
\text { (M€) }\end{array}$ & $\begin{array}{l}\text { Cost of low-emission } \\
\text { animal housing (M€) }\end{array}$ & $\begin{array}{l}\text { Economic benefit } \\
\text { of reducing } \mathrm{NH}_{3} \\
\text { emissions (M€) }\end{array}$ \\
\hline Austria & $1.80(1.58-2.01)$ & $5.32(3.34-7.30)$ & $5.70(5.29-6.11)$ & 84.29 (75.71-92.86) & 319.09 (153.96-482.30) \\
\hline Bulgaria & $0.27(0.24-0.30)$ & $0.80(0.50-1.09)$ & $0.85(0.79-0.92)$ & $12.63(11.35-13.92)$ & $101.19(49.06-152.72)$ \\
\hline Denmark & $3.13(2.75-3.50)$ & $9.26(5.82-12.70)$ & $9.92(9.20-10.64)$ & $146.62(131.70-161.54)$ & $212.31(101.47-321.09)$ \\
\hline Estonia & $0.53(0.47-0.59)$ & $1.56(0.98-2.15)$ & $1.68(1.55-1.80)$ & $24.78(22.25-27.30)$ & $97.63(47.49-147.79)$ \\
\hline Finland & $1.15(1.01-1.29)$ & $3.40(2.14-4.66)$ & $3.64(3.38-3.91)$ & $53.85(48.37-59.33)$ & 295.22 (83.47-478.66) \\
\hline France & $12.15(10.69-13.61)$ & $35.96(22.60-49.33)$ & $38.52(35.72-41.31)$ & $569.48(511.53-627.44)$ & 848.78 (409.80-1282.79) \\
\hline Germany & $31.94(28.11-35.78)$ & 94.56 (59.42-129.69) & $101.26(93.92-108.61)$ & $\begin{array}{l}1497.24(1344.86- \\
1649.62)\end{array}$ & $3652.42(1773.67-5514.07)$ \\
\hline Hungary & $2.56(2.25-2.87)$ & $7.57(4.76-10.39)$ & $8.11(7.52-8.70)$ & $119.92(107.71-132.12)$ & 164.99 (80.59-249.19) \\
\hline Ireland & $2.50(2.20-2.79)$ & $7.39(4.64-10.13)$ & $7.91(7.34-8.48)$ & $116.95(105.05-128.85)$ & $173.50(81.76-261.08)$ \\
\hline Latvia & $0.89(0.78-1.00)$ & $2.63(1.65-3.61)$ & $2.82(2.61-3.02)$ & $41.69(37.45-45.93)$ & $26.04(13.00-39.08)$ \\
\hline Luxembourg & $0.23(0.20-0.26)$ & $0.68(0.43-0.93)$ & $0.73(0.67-0.78)$ & 10.75 (9.65-11.84) & $25.19(9.28-38.04)$ \\
\hline Portugal & $0.52(0.45-0.58)$ & $1.53(0.96-2.09)$ & $1.64(1.52-1.75)$ & $24.18(21.72-26.64)$ & $113.80(46.21-172.04)$ \\
\hline Slovakia & $0.17(0.15-0.19)$ & $0.50(0.31-0.68)$ & $0.53(0.49-0.57)$ & $7.87(7.07-8.67)$ & $92.42(45.28-139.42)$ \\
\hline Spain & $7.03(6.19-7.88)$ & $20.81(13.08-28.55)$ & $22.29(20.67-23.91)$ & $329.56(296.02-363.10)$ & $182.47(88.59-274.13)$ \\
\hline Sweden & $2.10(1.85-2.36)$ & $6.23(3.91-8.54)$ & $6.67(6.18-7.15)$ & $98.60(88.56-108.63)$ & 648.43 (206.38-994.32) \\
\hline United Kingdom & $12.79(11.25-14.32)$ & $37.85(23.78-51.91)$ & $40.53(37.59-43.47)$ & $599.30(538.31-660.29)$ & 3416.25 (1652.69-5159.09) \\
\hline EU-16 & 79.75 (70.18-89.32) & $236.05(148.33-323.77)$ & $252.79(234.45-271.14)$ & $\begin{array}{l}3737.69(3357.30- \\
4118.08)\end{array}$ & $\begin{array}{l}10,369.74(4842.69- \\
15,705.82)\end{array}$ \\
\hline EU-28 & 79.75 (70.18-89.32) & $236.05(148.33-323.77)$ & $252.79(234.45-271.14)$ & $\begin{array}{l}3737.69(3357.30- \\
4118.08)\end{array}$ & $\begin{array}{l}13,488.21(6357.81- \\
20,414.03)\end{array}$ \\
\hline $\begin{array}{l}\text { EU-28 and neigh- } \\
\text { bouring non-EU } \\
\text { countries }\end{array}$ & 79.75 (70.18-89.32) & $236.05(148.33-323.77)$ & $252.79(234.45-271.14)$ & $\begin{array}{l}3737.69(3357.30- \\
4118.08)\end{array}$ & $\begin{array}{l}14,837.48(6976.17- \\
22,465.43)\end{array}$ \\
\hline
\end{tabular}

Numbers in parentheses represent uncertainty ranges as described in "Methods"

citizen). The associated annual economic benefit in the $28 \mathrm{EU}$ countries is $13,488 \mathrm{M} €$ (corresponding to $26 € /$ year per EU-28 citizen) and over the wider European domain it is $14,837 \mathrm{M} €$. The largest economic benefits are found for Germany (3652 M€) and the UK (3416 M€), i.e., the countries with the largest deviation in meeting the national emission reduction commitments.

Our estimates indicate that the regulation of $\mathrm{NH}_{3}$ emissions generates large health and economic benefits for the EU countries implementing the measures but also for the wider region. The relatively low level of emission reduction commitment for $\mathrm{NH}_{3}$ for EU-28, i.e., 6\%, can be achieved by the implementation of a relatively lowcost measure such as low nitrogen feed. The economic benefits from avoided premature deaths over Europe are orders of magnitude greater than the expenditure of implementing the low nitrogen feed abatement option. However, even for the least cost-effective measure (lowemission animal housing) the economic benefits are still fourfold of the costs. The benefit-to-cost ratios of the four $\mathrm{NH}_{3}$ abatement options range from $186(r$ : 99-252) for low nitrogen feed to $4(r: 2-5)$ for low-emission animal housing in Europe, with covered manure storage (63; $r$ : 47-69) and urea fertilizer application (59; $r$ : 30-83), in between. We have to note that these estimates are conservative because reduced morbidity has not been included, and we used IER functions that should be regarded as providing lower limit results for premature mortality. However, we also need to stress here that a small fraction of society, that is, 1.72 million holders of farms with livestock (for the three $\mathrm{NH}_{3}$ emission abatement options for the livestock sector) and 1.57 million holders of crop farms (for the $\mathrm{NH}_{3}$ emission abatement option for the crop sector) in 16 EU countries [22] may have to bear the costs of measures to abate $\mathrm{NH}_{3}$ emissions, while 510.2 million EU-28 citizens would benefit from the improvement of air quality. The loss of competitiveness of European farmers relative to those in non-EU 
countries with less stringent environmental policies, and the improvement of public health and economic benefits for the whole society indicate the need of redistributing such costs, for example through financial support of the implementation of $\mathrm{NH}_{3}$ abatement measures.

Wagner et al. [63] assessed the costs and benefits of manure storage cover and application techniques in Lower Saxony, Germany, and reported similar results as our findings. They found that the implementation of concrete storage covers and slurry injection could reduce $\mathrm{NH}_{3}$ emissions by $25 \%$ amounting to net benefits of $505 \mathrm{M} €$ and a benefit-to-cost ratio of 4.2. Similarly, Van Grinsven et al. [61] estimated that the social cost of the impacts of agricultural $\mathrm{NH}_{3}$ emissions in the EU-27 in 2008 was between 10 and 120 billion $€$ per year of which 5-65 billion $€$ were associated with air pollution effects on human health. They concluded that lowcost $\mathrm{NH}_{3}$ emission abatement measures (e.g., improved $N$ use efficiency) could lead to large reduction of air pollution with robust welfare increase. Hill et al. [36] showed that reduced air quality resulting from maize production is associated with 4300 premature deaths annually in the United States, with estimated damages in monetary terms of 39 billion USD. Ammonia emission reductions in maize production can be achieved by interventions such as change in fertilizer type and application method, improvement of nitrogen-use efficiency and switching to crops requiring less fertilizer.

\section{Conclusions}

By combining a regional integrated atmospheric model with non-market valuation techniques, we estimated the costs and the benefits of regulating $\mathrm{NH}_{3}$ emissions from agriculture over Europe. Our analysis indicates that meeting the requirements of national emission reduction commitments applicable from 2020 to 2029 set out in the Directive 2016/2284/EU can generate large health and economic benefits not only for the EU countries implementing the measures, but also for the wider region. Our findings highlight that much more ambitious reduction commitments for $\mathrm{NH}_{3}$ emissions could be applied by EU-28 countries with relatively minimal costs. Recent analyses of premature mortality attributable to PM2.5 indicate that our results represent a lower limit of the health and economic benefits from $\mathrm{NH}_{3}$ and other air pollution emission reductions.

The exceedance of economic benefits over farmers' abatement costs may indicate the need of transferring back part of the societal benefit of reduced $\mathrm{NH}_{3}$ emissions to the farmers in the form of investment support for the abatement measures. The CAP through rural development policy measures could strongly contribute to meeting those emission reduction commitments.
Domínguez et al. [15] showed that when subsidies are paid for the application of technological emission mitigation options, the share of mitigation achieved via technologies instead of production changes increases considerably, which has a minimal impact on farmers' profitability. Increasing the support for agricultural modernization and strengthening the training of European farmers could further foster the adoption of new technologies, thus improving the environmental and economic performance of European agriculture [29, 30]. The evaluation of agricultural nonpoint pollution control options for China demonstrated that the combination of subsidies to farmers for reducing fertilizer use with education and training on management techniques can be more successful than either policy option by itself [1]. Similarly, increasing awareness of the large contribution of animal husbandry to air pollution and human health may influence the general public to change the composition of their diet towards plant-based foods [58], while raising consumers' willingness to buy more environmentally friendly food can encourage farmers to adopt more sustainable practices [14].

Our monetization of the costs and the benefits of the compliance of agriculture with the current air quality targets provide European and national policy-makers with information for the formulation of (a) the national air pollution control programmes and (b) the national advisory code of good agricultural practices to control $\mathrm{NH}_{3}$ emissions. Our estimates can also support rural development policy measures under the new CAP post-2020. Our findings highlight the need for a better integration of agricultural and air quality policies that could further lead to reduced air pollution and health impacts in Europe. Future research could analyse the costs and benefits of $\mathrm{NH}_{3}$ emission abatement measures at a more disaggregated level, i.e., across agricultural systems. This will allow the formulation of specific recommendations for the different agricultural systems in individual European countries.

\section{Abbreviations \\ CAP: common agricultural policy; CO: carbon monoxide; EU: European Union; GBD: global burden of disease; GDP: gross domestic product; GFS: global forecast system; IER: integrated exposure-response; MOZART-4: Model for Ozone and Related chemical Tracers version 4; NEC: national emission ceilings; NCEP: National Center for Environmental Prediction; $\mathrm{NH}_{3}$ : ammonia; NMVOC: non-methane volatile organic compounds; NOx: nitrogen oxides; PM2.5: particulate matter with a diameter smaller than $2.5 \mu \mathrm{m}$; PM10: coarse particles with a diameter smaller than $10 \mu \mathrm{m}$; RR: relative risk; PPP: purchasing power parity; $\mathrm{SO}_{2}$ : sulphur dioxide; SOx: sulphur oxides; UK: United Kingdom; USD: United States Dollar; VSL: value of statistical life; WHO: World Health Organiza- tion; WRF/Chem: Weather Research and Forecast model coupled with the chemistry module; WTP: willingness to pay.}

\section{Acknowledgements}

Not applicable. 
Authors' contributions

EG conceptualized the study and conducted the economic analysis. JK conducted the atmospheric modelling analysis. $A B$ and $J$ provided advice on the methods. All authors contributed to the writing of the paper. All authors read and approved the final manuscript.

\section{Funding}

Not applicable.

\section{Availability of data and materials}

The datasets used and analysed during the current study are available from the corresponding author on reasonable request.

\section{Ethics approval and consent to participate}

Not applicable.

\section{Consent for publication}

Not applicable.

\section{Competing interests}

The authors declare that they have no competing interests.

\section{Author details}

${ }^{1}$ The Cyprus Institute, Energy Environment and Water Research Center, 20 Konstantinou Kavafi Street, Aglantzia, 2121 Nicosia, Cyprus. ${ }^{2}$ Atmospheric Chemistry Department, Max Planck Institute for Chemistry, 55128 Mainz, Germany.

\section{Appendix}

See Tables 4, 5 and 6.

Table 4 Summary of the model configuration processes used in the study

\begin{tabular}{|c|c|c|}
\hline Process & Option & References \\
\hline Microphysics & $\begin{array}{l}\text { Morrison 2-moment } \\
\text { scheme }\end{array}$ & Morrison et al. [50] \\
\hline Land surface & $\begin{array}{l}\text { NOAH land surface } \\
\text { model }\end{array}$ & Chen and Dudhia [12] \\
\hline Boundary layer & $\begin{array}{l}\text { Yonsei University (YSU) } \\
\text { planetary boundary } \\
\text { layer }\end{array}$ & Hong et al. [38] \\
\hline Cumulus & $\begin{array}{l}\text { Grell 3D ensemble } \\
\text { scheme }\end{array}$ & Grell and Devenyi [32] \\
\hline Surface layer & $\begin{array}{l}\text { MM5 similarity surface } \\
\text { layer scheme }\end{array}$ & Zhang and Anthes [65] \\
\hline Radiation & $\begin{array}{l}\text { Rapid radiative transfer } \\
\text { model (RRTTM) }\end{array}$ & lacono et al. [40] \\
\hline Gas-phase chemistry & $\begin{array}{l}\text { Second-generation } \\
\text { regional acid deposi- } \\
\text { tion model (RADM2) }\end{array}$ & Stockwell et al. [59] \\
\hline Aerosols & $\begin{array}{l}\text { Modal Aerosol Dynam- } \\
\text { ics Model for Europe } \\
\text { (MADE), Secondary } \\
\text { Organic Aerosol } \\
\text { Model (SORGAM) }\end{array}$ & $\begin{array}{l}\text { Ackermann et al. [2], } \\
\text { Schell et al. [57] }\end{array}$ \\
\hline
\end{tabular}

Table 5 Values for VSL in 2016 (with the range in parentheses) for the individual countries (EU and non-EU) studied

\begin{tabular}{|c|c|}
\hline Countries & VSL (M€) \\
\hline Luxembourg & $7.73(3.87-11.60)$ \\
\hline Norway & $5.18(2.59-7.77)$ \\
\hline Ireland & $4.95(2.48-7.43)$ \\
\hline Switzerland & $4.59(2.29-6.88)$ \\
\hline Austria & $4.19(2.09-6.28)$ \\
\hline Denmark & $4.10(2.05-6.15)$ \\
\hline Netherlands & $4.03(2.02-6.05)$ \\
\hline Sweden & $4.00(2.00-6.00)$ \\
\hline Germany & $3.93(1.96-5.89)$ \\
\hline Belgium & $3.86(1.93-5.79)$ \\
\hline United Kingdom & $3.68(1.84-5.52)$ \\
\hline Finland & $3.68(1.84-5.52)$ \\
\hline France & $3.44(1.72-5.16)$ \\
\hline Italy & $3.32(1.66-4.97)$ \\
\hline Spain & $3.10(1.55-4.65)$ \\
\hline Estonia & $3.03(1.52-4.55)$ \\
\hline Czech Republic & $2.96(1.48-4.44)$ \\
\hline Slovenia & $2.93(1.47-4.40)$ \\
\hline Cyprus & $2.92(1.46-4.38)$ \\
\hline Turkey & $2.88(1.44-4.31)$ \\
\hline Portugal & $2.76(1.38-4.14)$ \\
\hline Latvia & $2.68(1.34-4.02)$ \\
\hline Hungary & $2.63(1.31-3.94)$ \\
\hline Slovakia & $2.60(1.30-3.90)$ \\
\hline Romania & $2.52(1.26-3.78)$ \\
\hline Poland & $2.50(1.25-3.74)$ \\
\hline Greece & $2.45(1.22-3.67)$ \\
\hline Croatia & $2.31(1.16-3.47)$ \\
\hline Bulgaria & $2.06(1.03-3.09)$ \\
\hline Serbia & $1.92(0.96-2.87)$ \\
\hline Montenegro & $1.91(0.96-2.87)$ \\
\hline Ukraine & $1.91(0.95-2.86)$ \\
\hline Lebanon & $1.66(0.83-2.48)$ \\
\hline North Macedonia & $1.58(0.79-2.38)$ \\
\hline Jordan & $1.37(0.68-2.05)$ \\
\hline Bosnia and Herzegovina & $1.32(0.66-1.98)$ \\
\hline Albania & $1.27(0.64-1.91)$ \\
\hline Georgia & $1.24(0.62-1.87)$ \\
\hline
\end{tabular}


Table 6 Reduction in premature mortality resulting from the reduction of ammonia emissions over Europe in 2016

\begin{tabular}{|c|c|}
\hline Countries & Number of premature deaths \\
\hline Germany & $930.4(818.0-1022.5)$ \\
\hline United Kingdom & $928.2(809.0-1022.2)$ \\
\hline Italy & $447.6(391.0-494.8)$ \\
\hline France & $246.6(214.0-273.0)$ \\
\hline Poland & $176.1(156.0-192.8)$ \\
\hline Sweden & $162.1(87.0-192.3)$ \\
\hline Montenegro & $143.8(126.0-158.8)$ \\
\hline Serbia & $143.8(126.0-158.8)$ \\
\hline Ukraine & $120.6(107.0-131.8)$ \\
\hline Czechia & $90.0(80.0-98.5)$ \\
\hline Finland & $80.3(39.0-109.9)$ \\
\hline Austria & $76.2(66.0-84.4)$ \\
\hline Belgium & $73.2(66.0-79.5)$ \\
\hline Netherlands & $70.6(62.0-77.1)$ \\
\hline Hungary & $62.8(56.0-69.2)$ \\
\hline Spain & $58.9(66.0-56.0)$ \\
\hline Denmark & $51.8(44.0-57.6)$ \\
\hline Bulgaria & $49.1(43.0-53.8)$ \\
\hline Switzerland & $48.7(42.0-54.1)$ \\
\hline Greece & $46.5(42.0-50.9)$ \\
\hline Romania & $44.8(39.0-49.3)$ \\
\hline Portugal & $41.2(28.0-45.7)$ \\
\hline Croatia & $36.4(32.0-39.8)$ \\
\hline Slovakia & $35.6(32.0-38.9)$ \\
\hline Ireland & $35.0(29.0-37.4)$ \\
\hline Estonia & $32.2(36.0-28.4)$ \\
\hline Norway & $31.9(15.0-41.9)$ \\
\hline Bosnia and Herzegovina & $29.1(25.0-32.1)$ \\
\hline Turkey & $23.1(20.0-25.5)$ \\
\hline Albania & $17.3(15.0-19.2)$ \\
\hline Slovenia & $14.8(13.0-16.4)$ \\
\hline Northern Macedonia & $14.7(13.0-16.2)$ \\
\hline Lebanon & $12.9(11.0-14.1)$ \\
\hline Latvia & $9.7(10.0-10.0)$ \\
\hline Georgia & $5.0(4.0-5.4)$ \\
\hline Luxembourg & $3.3(2.0-3.6)$ \\
\hline Cyprus & $2.3(2.0-2.4)$ \\
\hline Jordan & $2.0(2.0-2.2)$ \\
\hline
\end{tabular}

Numbers in parentheses represent the $95 \%$ confidence intervals to reflect associated uncertainty

Received: 18 September 2019 Accepted: 26 November 2019 Published online: 17 December 2019

\section{References}

1. Abler D (2015) Economic evaluation of agricultural pollution control options for China. J Integr Agric 14(6):1045-1056
2. Ackermann IJ, Hass H, Memmesheimer M, Ebel A, Binkowski FS, Shankar U (1998) Modal aerosol dynamics model for Europe: development and first applications. Atmos Environ 32:2981-2999

3. Amster E, Levy CL (2019) Impact of coal-fired power plant emissions on children's health: a systematic review of the epidemiological literature. Int J Environ Res Public Health 16(11):2008

4. Backes AM, Aulinger A, Bieser J, Matthias V, Quante M (2016) Ammonia emissions in Europe, part II: how ammonia emission abatement strategies affect secondary aerosols. Atmos Environ 126:153-161

5. Banzhaf S, Schaap M, Wichink Kruit RK, Denier Van Der Gon HAC, Stern R, Builtjes PJH (2013) Impact of emission changes on secondary inorganic aerosol episodes across Germany. Atmos Chem Phys 13:23

6. Bauer SE, Tsigaridis K, Miller R (2016) Significant atmospheric aerosol pollution caused by world food cultivation. Geophys Res Lett 43(10):5394-5400

7. Behera SN, Sharma M (2010) Investigating the potential role of ammonia in ion chemistry of fine particulate matter formation for an urban environment. Sci Total Environ 408(17):3569-3575

8. Berger A, Barbet C, Leriche M, Deguillaume L, Mari C, Chaumerliac N, Bègue N, Tulet P, Gazen D, Escobar J (2016) Evaluation of Meso-NH and WRF/CHEM simulated gas and aerosol chemistry over Europe based on hourly observations. Atmos Res 176-177:43-63

9. Bessagnet B, Beauchamp M, Guerreiro C, De Leeuw F, Tsyro S, Colette A, Meleux F, Rouil L, Ruyssenaars P, Sauter F, Velders GJ (2014) Can further mitigation of ammonia emissions reduce exceedances of particulate matter air quality standards? Environ Sci Policy 44:149-163

10. Burnett RT, Pope CA III, Ezzati M, Olives C, Lim SS, Mehta S, Shin HH, Singh G, Hubbell B, Brauer M, Anderson HR (2014) An integrated risk function for estimating the global burden of disease attributable to ambient fine particulate matter exposure. Environ Health Perspect 122(4):397-403

11. Burnett R, Chen H, Szyszkowicz M, Fann N, Hubbell B, Pope CA, Apte JS, Brauer M, Cohen A, Weichenthal S, Coggins J (2018) Global estimates of mortality associated with long-term exposure to outdoor fine particulate matter. Proc Natl Acad Sci 115(38):9592-9597

12. Chen F, Dudhia J (2001) Coupling an advanced land surface hydrology model with the Penn State-NCAR MM5 modeling system. Part I: model implementation and sensitivity. Mon Weather Rev 129:569-585

13. Cohen AJ, Brauer M, Burnett RT, Anderson HR, Frostad J, Estep K et al (2017) Estimates and 25-year trends of the global burden of disease attributable to ambient air pollution: an analysis of data from the Global Burden of Diseases Study 2015. Lancet 389(10082):1907-1918

14. Dessart FJ, Barreiro-Hurlé J, van Bavel R (2019) Behavioural factors affecting the adoption of sustainable farming practices: a policy-oriented review. Eur Rev Agric Econ 46(3):417-471

15. Domínguez IP, Fellmann T, Weiss F, Witzke P, Barreiro-Hurlé J, Himics M, Jansson T, Salputra G, Leip A (2016) An economic assessment of GHG mitigation policy options for EU agriculture (ECAMPA 2). JRC Science for Policy Report, EUR 27973 EN, https://doi.org/10.2791/843461

16. Emmons LK, Walters S, Hess PG, Lamarque JF, Pfister GG, Fillmore D, Granier C, Guenther A, Kinnison D, Laepple T, Orlando J, Tie X, Tyndall G, Wiedinmyer C, Baughcum SL, Kloster S (2010) Description and evaluation of the Model for Ozone and Related chemical Tracers, version 4 (MOZART-4). Geosci Model Dev 3:43-67

17. European Commission (2013) Clean air policy package-commission staff working document. Impact assessment (SEC(2005) 1133)/Annex to $\operatorname{COM}(2005)$ 446/447

18. European Commission (2017) Clean air forum—summary report. Paris

19. European Commission (2018) Proposal for a Regulation of the European Parliament and of the Council establishing rules on support for strategic plans to be drawn up by Member States under the Common agricultural policy (CAP Strategic Plans) and financed by the European Agricultural Guarantee Fund (EAGF) and by the European Agricultural Fund for Rura Development (EAFRD) and repealing Regulation (EU) No 1305/2013 of the European Parliament and of the Council and Regulation (EU) No 1307/2013 of the European Parliament and of the Council. Brussels, COM/2018/392 final

20. European Commission (2019) 2014-2020 EAFRD funding per Member State (EUR million). https://ec.europa.eu/agriculture/sites/agriculture/files 
/rural-development-2014-2020/country-files/common/funding-perms_en.pdf. Accessed 17 June 2019

21. Eurostat (2019a) Ammonia emissions from agriculture [sdg_02_60]. https://ec.europa.eu/eurostat/tgm/table.do?tab=table\&init=1\&plugi $\mathrm{n}=1$ \&language $=$ en\&pcode $=$ sdg_02_60. Accessed 1 Feb 2019

22. Eurostat (2019b) Farm indicators by agricultural area, type of farm, standard output, legal form and NUTS 2 regions [ef_m_farmleg]. https://appss o.eurostat.ec.europa.eu/nui/show.do?dataset=ef_m_farmleg\&lang=en. Accessed 13 Nov 2019

23. EEA (2019) National emission ceilings directive emissions. European Environment Agency. https://www.eea.europa.eu/data-and-maps/dashb oards/necd-directive-data-viewer-1. Accessed 5 Feb 2019

24. Fast JD, Gustafson WI Jr, Easter RC, Zaveri RA, Barnard JC, Chapman EG, Grell GA (2006) Evolution of ozone, particulates, and aerosol direct forcing in an urban area using a new fully-coupled meteorology, chemistry, and aerosol model. J Geophys Res Atmos. https://doi.org/10.1029/2005j d006721

25. Farrance I, Frenkel R (2012) Uncertainty of measurement: a review of the rules for calculating uncertainty components through functional relationships. Clin Biochem Rev 33:49

26. GBD (2016) IER estimates: https://cloud.ihme.washington.edu/index .php/s/puzbu28QteEHTmS. Accessed 4 Nov 2019

27. Ghude SD, Chate DM, Jena C, Beig G, Kumar R, Barth MC, Pfister GG, Fadnavis S, Pithani P (2016) Premature mortality in India due to PM2. 5 and ozone exposure. Geophys Res Lett 43(9):4650-4658

28. Giannadaki D, Giannakis E, Pozzer A, Lelieveld J (2018) Estimating health and economic benefits of reductions in air pollution from agriculture. Sci Total Environ 622:1304-1316

29. Giannakis E, Bruggeman A (2015) The highly variable economic performance of European agriculture. Land Use Policy 45:26-35

30. Giannakis E, Bruggeman A (2018) Exploring the labour productivity of agricultural systems across European regions: a multilevel approach. Land Use Policy 77:94-106

31. Giannakis E, Kushta J, Giannadaki D, Georgiou GK, Bruggeman A, Lelieveld $J$ (2019) Exploring the economy-wide effects of agriculture on air quality and health: evidence from Europe. Sci Total Environ 663:889-900

32. Grell GA, Devenyi D (2002) A generalized approach to parameterizing convection combining ensemble and data assimilation techniques. Geophys Res Lett 29:10-13

33. Grell GA, Peckham SE, Schmitz R, McKeen SA, Frost G, Skamarock WC, Eder B (2005) Fully coupled "online" chemistry within the WRF model. Atmos Environ 39:6957-6975

34. Guo H, Otjes R, Schlag P, Kiendler-Scharr A, Nenes A, Weber RJ (2018) Effectiveness of ammonia reduction on control of fine particle nitrate. Atmos Chem Phys 18(16):12241-12256

35. Hammitt JK (2000) Valuing mortality risk: theory and practice. Environ Sci Technol 34:1396-1400

36. Hill J, Goodkind A, Tessum C, Thakrar S, Tilman D, Polasky S, Smith T, Hunt N, Mullins K, Clark M, Marshall J (2019) Air-quality-related health damages of maize. Nat Sustain 2(5):397

37. Hoek G, Krishnan RM, Beelen R, Peters A, Ostro B, Brunekreef B, Kaufman JD (2013) Long-term air pollution exposure and cardio-respiratory mortality: a review. Environ Health 12(1):43

38. Hong SY, Noh Y, Dudhia J (2006) A new vertical diffusion package with an explicit treatment of entrainment processes. Mon Weather Rev 134:2318-2341

39. Houlton BZ, Almaraz M, Aneja V, Austin AT, Bai E, Cassman KG, Compton JE, Davidson EA, Erisman JW, Galloway JN, Gu B (2019) A world of cobenefits: solving the global nitrogen challenge. Earth's Future 7:865-872

40. Iacono MJ, Delamere JS, Mlawer EJ, Shephard MW, Clough SA, Collins WD (2008) Radiative forcing by long-lived greenhouse gases: calculations with the AER radiative transfer models. J Geophys Res Atmos 113:D13103

41. Janssens-Maenhout G, Dentener F, van Aardenne J, Monni S, Pagliari V, Orlandini L, Klimont Z, Kurokawa J, Akimoto H, Ohara T, Wankmüller R, Battye B, Grano D, Zuber A, Keating T (2012) EDGAR-HTAP: a harmonized gridded air pollution emission dataset based on national inventories. European Commission, Joint Research Centre, Institute for Environment and Sustainability, Luxemburg

42. Klimont Z, Winiwarter W (2011) Integrated ammonia abatement-modelling of emission control potentials and costs in GAINS. IIASA interim report. IIASA, Laxenburg, Austria, IR-11-027
43. Krewski D, Jerrett M, Burnett RT, Ma R, Hughes E, Shi Y, Turner MC, Pope CA III, Thurston G, Calle EE, Thun MJ (2009) Extended follow-up and spatial analysis of the American Cancer Society study linking particulate air pollution and mortality (No. 140). Health Effects Institute, Boston

44. Kushta J, Pozzer A, Lelieveld J (2018) Uncertainties in estimates of mortality attributable to ambient PM2.5 in Europe. Environ Res Lett 13(6):064029

45. Lelieveld J, Evans JS, Fnais M, Giannadaki D, Pozzer A (2015) The contribution of outdoor air pollution sources to premature mortality on a global scale. Nature 525(7569):367

46. Lelieveld J, Haines A, Pozzer A (2018) Age-dependent health risk from ambient air pollution: a modelling and data analysis of childhood mortality in middle-income and low-income countries. Lancet Planet Health 2(7):e292-e300

47. Lelieveld J, Klingmüller K, Pozzer A, Pöschl U, Fnais M, Daiber A, Münzel T (2019) Cardiovascular disease burden from ambient air pollution in Europe reassessed using novel hazard ratio functions. Eur Heart $J$ 40(20):1590-1596

48. Liu M, Huang $X$, Song $Y$, Tang J, Cao J, Zhang $X$, Zhang Q, Wang S, Xu T, Kang L, Cai X (2019) Ammonia emission control in China would mitigate haze pollution and nitrogen deposition, but worsen acid rain. Proc Natl Acad Sci 116(16):7760-7765

49. Megaritis AG, Fountoukis C, Charalampidis PE, Pilinis C, Pandis SN (2013) Response of fine particulate matter concentrations to changes of emissions and temperature in Europe. Atmos Chem Phys 13:3423-3443

50. Morrison H, Curry JA, Khvorostyanov VI (2005) A new double-moment microphysics parameterization for application in cloud and climate models. Part l: description. J Atmos Sci 62:1665-1677

51. OECD (2012) Mortality risk valuation in environment, health and transport policies. OECD Publishing, Paris. https://doi.org/10.1787/9789264130 807-en

52. OECD (2016) The economic consequences of outdoor air pollution. OECD Publishing, Paris. https://doi.org/10.1787/9789264257474-en

53. Oenema O, Velthof G, Klimont Z, Winiwarter W (2012) Emissions from agriculture and their control potentials. IIASA TSAP report 3, Version 2.1

54. Park RS, Lee S, Shin SK, Song CH (2014) Contribution of ammonium nitrate to aerosol optical depth and direct radiative forcing by aerosols over East Asia. Atmos Chem Phys 14(4):2185-2201

55. Perrone MG, Larsen BR, Ferrero L, Sangiorgi G, De Gennaro G, Udisti R, Zangrando R, Gambaro A, Bolzacchini E (2012) Sources of high PM2. 5 concentrations in Milan, Northern Italy: molecular marker data and CMB modelling. Sci Total Environ 414:343-355

56. Pozzer A, Tsimpidi AP, Karydis VA, De Meij A, Lelieveld J (2017) Impact of agricultural emission reductions on fine-particulate matter and public health. Atmos Chem Phys 17(20):12813

57. Schell B, Ackermann IJ, Hass H, Binkowski FS, Ebel A (2001) Modeling the formation of secondary organic aerosol within a comprehensive air quality model system. J Geophys Res 106:28275-28293

58. Sheppard SC, Bittman S (2015) Linkage of food consumption and export to ammonia emissions in Canada and the overriding implications for mitigation. Atmos Environ 103:43-52

59. Stockwell WR, Middleton P, Chang JS, Tang X (1990) The second generation regional acid deposition model chemical mechanism for regional air quality modelling. J Geophys Res 95:16343-16367

60. Tuccella P, Curci G, Visconti G, Bessagnet B, Menut L, Park RJ (2012) Modeling of gas and aerosol with WRF/Chem over Europe: evaluation and sensitivity study. J Geophys Res 117:D03303

61. Van Grinsven HJ, Holland M, Jacobsen BH, Klimont Z, Sutton MA, Jaap Willems W (2013) Costs and benefits of nitrogen for Europe and implications for mitigation. Environ Sci Technol 47(8):3571-3579

62. Vodonos A, Awad YA, Schwartz I (2018) The concentration-response between long-term PM2. 5 exposure and mortality; A meta-regression approach. Environ Res 166:677-689

63. Wagner S, Angenendt E, Beletskaya O, Zeddies J (2017) Assessing ammonia emission abatement measures in agriculture: farmers' costs and society's benefits - a case study for Lower Saxony, Germany. Agric Syst 157:70-80

64. Wang T, Zhao B, Liou KN, Gu Y, Jiang Z, Song K, Su H, Jerrett M, Zhu Y (2019) Mortality burdens in California due to air pollution attributable to local and nonlocal emissions. Environ Int 133:105232 
65. Zhang D, Anthes RA (1982) High-resolution model of the planetary boundary layer — sensitivity tests and comparisons with SESAME-79 data. J Appl Meteorol 21(1594-1609):6120

\section{Publisher's Note}

Springer Nature remains neutral with regard to jurisdictional claims in published maps and institutional affiliations.
Submit your manuscript to a SpringerOpen ${ }^{\odot}$ journal and benefit from:

- Convenient online submission

- Rigorous peer review

- Open access: articles freely available online

- High visibility within the field

- Retaining the copyright to your article

Submit your next manuscript at $\boldsymbol{\nabla}$ springeropen.com 